\title{
O HOMEM É ESPÍRITO NA CARNE
}

http://dx.doi.org/10.11606/issn.2175-3180.v13i26p163-167

Paulo Ferreira ${ }^{\mathrm{I}}$

De Marília, núbil dondoca, herdei herpes labial, uma joelhada no estômago e uma ressaca de cerveja convertida em camisa vomitada. Cátia Silva, a promíscua da escola secundária que rodava os ladinos da aldeia, prostrou-me três semanas com doença venérea sarada com água oxigenada e exasperadas súplicas a deus nosso senhor. Lúcia, neta de Mariela, pegou-me varicela e uma halitose de cabeça de alho. Marlene Roliça, alcunhada de Cotonete, rompeu relação sem aviso prévio ou exibir sinais de saturação, e introduziu-me à inalação de tabaco como cura para ataques de pânico. Ao montar na motorizada de Alex Curto, aprendiz de trolha cujas calejadas mãos tinham fama de operar maravilhas em termos de chapar cimento no tijolo e apalpar os seios às garinas, a estrábica musa Raquel votou-me a quatro meses de aguda choradeira. Que dizer de Anabela Trambolho, tresloucada a quem paguei roupas no centro comercial e escrevi cartas românticas em papel de cartolina, e que me traiu numa discoteca de província, abocanhando a língua de outro pacóvio? Nestas alturas, acode-me a pálida figura de Adérito, pintor de paredes que cem vezes perdoava se cem vezes fosse traído. Seria um rei, se pensasse como Adérito. Estou só. Reneguei dores, evidências, mas não fui Adérito, o famigerado Adérito que se borrava nas calças nos intervalos da escola primária e dormia enrolado em plástico para não manchar o colchão. Anabela Trambolho rastejava e grudava-se-me aos joelhos e, ainda com a saliva do pacóvio molhando-lhe os bigodes, pedia perdão, perdoa, bebé. Perdoei a morsa Anabela, neguei a traição, convenci-me da normalidade de suas imoralidades carnais. Dizia a mim mesmo que a infelicidade

I Universidade da Carolina do Norte, Chapel Hill, Carolina do Norte, EUA. 
inclinava as pessoas para comportamentos de que posteriormente se arrependiam, mas a desleixada Anabela prosseguiu com as traições. Como resultado, tentei repor ordem cósmica ao atirar-me para debaixo de um autocarro que travou antes de me esmagar.

Saudades, amor. A ladainha é para chegar a ti, Sara, meu bombom de licor amargo. No outro dia, ao divisar uma madame lendo poesia foleira na esplanada, acudiu-me um desejo de estar contigo. Ela esticoume o braço para que lhe osculasse a mão. Chamava-se Odete e, tal como tu, ria sem mostrar os dentes e falava sem mover os lábios. Não lhe resisti e mordi-lhe a orelha e exclamei que a adorava e glorificava. Arrogante, ela empurrou-me com tanta pujança e repulsa que torci o pé e bati com as costelas no alcatrão. O empregado do café veio em seu socorro e escorraçou-me à patada, como um cão sarnento. A consequência disto foi uma manhã passada na sala de espera do hospital. O convívio com as mulheres não me tem sido favorável, acabo macambúzio e desintegro-me à noite, chupando cigarrilhas e contando estrelas. Defeito de fabrico, míngua de afeição materna, não sei, o tambor interior mostra-se fraco. Raras vezes fui correspondido em questões sentimentais, vergasto-me rememorando horrorosos finais de relação, flechas em forma de palavras: não, adeus, és mais amigo, a culpa é minha e não tua. Nunca me feriu tanto a incomunicabilidade como agora. Sou incompatível com mulheres. Constato, pesaroso, que não há gato ou livro que me ajeite a manta e me aqueça o chá de limão e me passe a ferro a camisa e me frite um par de ovos no fogão e me massaje os olhos cansados de ler.

Que pena ter queimado livro da autoria de um escritor português deveras famoso nos anos sessenta do século passado. Um escritor esfíngico cuja imagem de intelectual fumando nas traseiras da escola apequenava este projeto de aprendiz de versejador. Um talentosíssimo escriba que aspirava a luz das formigas que o circundavam. Foi ele quem gravou a seguinte frase na pedra: "Mais forte que a certeza da inutilidade da dor é a absoluta presença da dor." Como me reconfortava a leitura desse livro na adolescência, quando tinha dezasseis ou dezassete anos e procurava sedativo espiritual. "Somos homens, não somos deuses nem pedras."

Soubesse eu por onde andas, Sara, cruzasse-me eu contigo, e menos me afligiriam as recordações. Que digo? Se nos encontrássemos, desfaleceria. Colapso cardíaco imediato, a depressão roçaria a facada nos pulsos. Se te avistasse com esse matulão musculado ao qual colocas 
açaime antes de sair de casa, escavaria a cova e lá permaneceria até que as larvas me tragassem.

"Coragem para se suicidar, possui?", questiona-me o gato. Massajo pistola imaginária, abro a boca e disparo. Sobressaltam-me sucessivas humilhações. Desde que nasci que convivo com gozos e rejeições. Ainda coro com a traição de Anabela na discoteca, com as risadas do aleijadinho mental que lambeu as beiças da Belinha. O suicídio é o supremo protesto. Mato-me como reivindicação do posto de trabalho que não me ofereceram, das oportunidades que, por azar ou estultícia, me passaram ao lado. O tiro na boca seria o protesto mais adequado contra esta coisa de ter sido cuspido pelo útero materno. Um vagido contra a existência.

Falta-me em rebeldia o que abunda em acanhamento. Conformome às regras, mesmo às regras que não estão escritas em lado algum, temo repreensões vindas de fictícios superiores hierárquicos, aceno que sim em sinal de obediência à autoridade, e até a agentes de trânsito bato continência. Não excedo as fronteiras do medo. Até namoradinhas de liceu respeitei em demasia. Namorava sem tocar nas carnes das moças, minhas mãos não desciam do nível do tronco feminino-as nádegas das meninas escaldavam-me as pontas dos dedos. Não ultrapassei as barreiras da nudez, tocar nas partes íntimas de uma mulher era tabu, razão para me resignar ao celibato. Similares cautelas aplico aos escassos trabalhos em que me envolvi. Abstenho-me de candidaturas a emprego receando não corresponder ao que é exigido, receando expor a mediania, a minha limitação cognitiva. Nunca ergui o braço na sala de aula. Coitado de mim, autista.

A ideia de desaparecer do mundo agrada-me, mas morrer com a bala na bocarra seria oferecer imerecida glória à desaparecida. Sara celebraria a notícia do meu desaparecimento com gargalhadas e breves afirmações de circunstância: "Oh, morreu o pobretanas, traste, pobrezinho. Deus o guarde." Conheço-a bem, sei como é estúpida. Imagino que conserva o hábito de se queixar dos meus defeitos, desta enfadonha personalidade que a ninguém traz alegria. Que importa revelar que por ela me apaixonei mal a vi? Ela responde sempre com coices, é mulher de pouca cortesia, não se rebaixa à vaidade alheia, nem se acabrunha sabendo da sua vulgaridade. Dir-me-ia ela que passou, que ninguém volta ao que deixou, que aquilo que sentiu por mim, se é que algum dia por mim nutriu sentimentos, não existe mais. Os pássaros chilreiam nas árvores que 
agonizam em frente à pensão, taxistas e reformados discutem jogando dominó no parque, um par de estudantes apaixonados estuda para o exame final, crianças pontapeiam a bola no relvado. Tudo me lembra de ti, Sara, embora eu intua que o amor se extraviou.

Por que motivo não juntei os trapinhos à prostituta? Mulher gentil, dócil, não me daria problemas. Quiçá me viesse a incomodar a sua profissão, o contacto diário com outros homens. Sentes minha ausência, Sara, pequerrucha? Este silêncio ensurdecedor bate-me na nuca como uma chapada. Os passarinhos chilreiam nas árvores enfermas, as crianças berram, eu não sei do teu paradeiro.

Tanta solenidade no sofrimento. Irrita-me não saber como descansar do luto. Ricardo, por exemplo, matou-se em protesto contra a noiva que o abandonou no altar. $\mathrm{O}$ suicídio como revolução. Ninguém se mata por razão nenhuma. "Querida", disse Leónidas à esposa. "Vou ali ao café jogar sueca com a rapaziada, sou capaz de chegar tarde a casa, talvez me mate." Gente como Leónidas não abunda. Respeito pelos corajosos, senhores. Suicidamo-nos em revolução contra nós mesmos e contra a asfixiante realidade exterior. A quem protesta com o revólver não é possível recomeçar, e aí reside um problema: o chumbo conclui o protesto. Não me atrevo a revoluções por intermédio de balázios na garganta. Ainda que a mulher me chorasse a morte, eu já seria cadáver furado pela bala, não retornaria para desabar sobre aquela que me surripiou a alegria. Mato-me por amor, e amo já roxo e verde e lombriga, rebelo-me entabuado no caixão. Morrer em vão. Não me iludo com protestos ou revoluções, nem sou bicho agitado, amanso com biscoitos, uma festinha no ombro fortaleceme para a refrega. Morrer por ti, Sara, quando partilhas o leito com um calhorda mais feio do que eu? Morro por mim.

Tiveste a tua fase política, Sara. Pregavas-te à televisão comentando os populistas, insultando os demagogos, rezavas pelo Fidel Castro, rasgavas o sutiã em defesa da libertação árabe. Eu odiava aquelas noitadas em bares em que a desoras proclamavas apego à transformação social, em que te declaravas louca pelo Che. Choninhas como sou, anuía, ecoava tuas revolucionárias juras, embandeirava contra a guerra do Iraque, contra o saque do petróleo levado a cabo por imperialistas ianques. Coro à distância, não sou igual a ti. Refuto causas, mártires, viro a cara se me encherem de assuntos políticos. Não abrirei um buraco na testa em tua memória, não vales o preço de um cartuxo de espingarda. 
O homem apanha-se a sós com o futuro. Não contem com o suicídio deste solitário. Não me suicido, que absurdo, matar-me com um punhal, beber uma pipa de vinho e trucidar os amanhãs longínquos. Esperem sentados. Hoje estou só, mas amanhã dispo uma rainha e mordo-lhe os ombros e o nariz e o peito e apaixono-me outra vez, e se outra mulher não vier, abraço a solidão, feliz por deslembrar teu corpo quando encaixava no meu e suávamos e gemíamos. Revivo uma madrugada no bar em que, de perna cruzada e cabelos ao vento, peroravas sobre as virtudes de ser marxista numa sociedade materialista. Enquanto papagueavas, eu salivava por teus lábios. Sinto a tua falta, patroa, reconheço que teu cheiro ainda me consome, confesso que bastaria um estalar de dedos teu e chegaria a ti, mesmo que me forçassem a rebolar numa estrada de pregos. Adormeço triste. Miau. Beija-me, gato. Convence-me de que isto é uma anedota.

Recebido em 13 de maio de 2021

Aprovado em 12 de dezembro de 2021

Paulo Ferreira

Lecturer na University of North Carolina - Chapel Hill. Doutor e Mestre em História pela Universidade de Lisboa.

Contato: paulorf@email.unc.edu

(D) : http://orcid.org/0000-0002-6698-0860

\footnotetext{
A Revista Desassossego utiliza a Licença Creative Commons Attribution que permite o compartilhamento do trabalho com reconhecimento da autoria e publicação inicial neste veículo - Attribution-NonCommercial-NoDerivates 4.0 International (CC BY-NC-ND 4.0), e reconhece que os Autores têm autorização prévia para assumirem contratos adicionais separadamente para distribuição não-exclusiva de versão dos seus trabalhos publicados, desde que fique explicitado o reconhecimento de sua autoria e a publicação inicial nesta revista.
} 